\title{
Cash Conversion Cycle and Firms' Profitability - A Study of Listed Manufacturing Companies of Pakistan
}

\author{
${ }^{1}$ Raheem Anser, ${ }^{2}$ Qaisar Ali Malik \\ ${ }^{I}$ Department of Business \& Economics, FURC. \\ ${ }^{2}$ Assistant Professor, Department of Business \& Economics, FURC.
}

\begin{abstract}
Cash conversion cycle is one of the most widely used measures to evaluate and measure the risks and returns associated to liquidity management Since every corporate organization is extremely concerned about how to sustain and improve profitability, hence they have to keep an eye on the factors affecting the profitability. The present study is concerned about evaluating how cash conversion cycle affects the profitability of manufacturing sector organizations listed at Karachi stock exchange of Pakistan. The specific research objective of the study is to investigate the existing literature on the role of cash conversion cycle in enhancing return on assets and equity of the companies and to measure the impact of cash conversion cycle on profitability of the manufacturing companies. The results of the study will be helpful for academics and industry experts for policy making and control purposes. The study takes return on equity and return on assets as measures of profitability to represent dependent variables. Firm size and debt ratio are taken as control variables. Cash conversion cycle is considered as independent or explanatory variable. Study takes into consideration 5 years financial statements data starting from 2007 to 2011. Results showed that manufacturing companies are having low average return on asset and high average return on equity with reasonable average cash conversion cycle. Regression results after adjusting for heteroskedasticity of data to minimize the effects of outliers, showed that cash conversion cycle is having significantly inverse association with both return on assets and equity indicating that lesser the cash conversion cycle greater would be the profitability measured through return on assets and equity. Hence the receivable collection period and inventory selling period must be reduced along with the extension of payment period to increase the profitability of manufacturing sector organizations. The study suggested that manufacturing companies are required to well estimate and evaluate the cash flows of the business, to well identify the long run and short run cash inflows and outflows to timely sort out the cash shortages and excess to formulate financing and investing strategies respectively.
\end{abstract}

Keywords: Cash Conversion Cycle, Return on Assets, Return on Equity, Profitability, Size, Debt

\section{Introduction}

Liquidity management has been one of the most crucial financial management domains since it involves intense tradeoffs between risks and returns associated to short term asset and liabilities management (Jose, 1996; Lancaster, 1999; Farris \& Hutchison, 2002). Cash conversion cycle is one of the most widely used measures to evaluate and measure the risks and returns associated to liquidity management (Moss \& Stine, 1993; Bodie \& Merton, 2000; Keown , 2003; Appuhami, 2008). It measures the time it takes to convert cash into cash again from the time when inventory is bought till the time inventory is sold and the bills are recovered (Padachi, 2006). Cash conversion cycle of individual firms as well the collective cycle of the industry, highlights how the firms are performing; moreover it also helps to dig out the areas where further improvement is required (Hutchison, 2007). For the business owners, one of the most important tasks is to estimate and evaluate cash flows of the business, to well identify the long run and short run cash inflows and outflows to timely sort out the cash shortages and excess to formulate financing and investing strategies respectively. It also helps in planning the payments to creditors on time to avoid losing reputation and trust of the customers and to avoid potential bankruptcy. Generally cash management is based on cash conversion cycle and is considered as important factors enhancing the performance of companies, since it shows how efficient a firm is in its payments of bills, collection of payments, and selling of inventory. Companies can enhance their profitability by lessening their length of cash conversion cycle through decreasing or lessening the receivables collection period, decreasing or lessening the inventory selling period and increasing or lengthening the credit payment period.

Since every corporate organization is extremely concerned about how to sustain and improve profitability, hence they have to keep an eye on the factors affecting the profitability. In this regard, liquidity management having its implications on risks and returns of the corporate organizations cannot be overlooked by these organizations and hence cash conversion cycle being indicator of the liquidity management needs to be explored as to how it may affect the profitability of the corporate units. Today due to changing world's economy, advancement of technology and increased global competition among the companies, every company 
is striving to enhance their profits and for that companies are putting every effort to bring their cash conversion cycle at optimum level to increase profitability.

The present study is concerned about evaluating and measuring about how the changes in cash conversion cycle affects the changes in the profitability of the manufacturing sector organizations listed at Karachi stock exchange of Pakistan.

\section{Objective of Study}

The specific research objective of the study is to investigate the existing literature on the role of cash conversion cycle in enhancing profitability of the companies and to measure the role of cash conversion cycle in explaining the variations in the profitability of the listed manufacturing companies of Pakistan.

\section{Scope of Study}

The study considers only the listed manufacturing sector companies of Karachi stock exchange of Pakistan.

\section{Significance of Study}

The results of the study will be helpful for academics and industry experts for policy making and control purposes.

\section{Literature Review}

Earlier literature has explored different variables representing liquidity and its effect on profitability and examined the relationship of accounts payable management, accounts receivables management, inventory management and cash to cash cycle management with profitability management, providing with different results as per how the length of cash cycle has been affecting profitability using different proxies for profitability (Deloof, 2003; Abdullatif \& AlHajjar, 2004; Nobanee, 2005; Lazaridis \& Tryfonidis, 2006; Raheman \& Nasr, 2007; Demirgunes \& Samiloglu, 2008; Enqvist et al., 2008; Stephanou et al. 2010; Raheman et al., 2010; Mathuva, 2010; Danuletiu, 2010; Alipour, 2011).

Richards \& Laughlin (1980) presented the idea of cash conversion cycle as a tool for measuring the liquidity management and performance of a company. Gentry et al. (1990) suggested that cash conversion cycle affects the market value of a firm. Lamberson (1991) suggested, during expansion in economics, liquidity increases to some extent by working capital management but there is no noticeable change seen during economic slowdown. Schilling (1996) proved that the increase in cash conversion cycle increases the minimum liquidity requirements of the business organizations and similarly decrease in cash conversion cycle decreases the minimum liquidity requirements of the business organizations. Schilling (1996) stated that the optimal level of liquidity position is obtained at minimized level of liquidity therefore the deployment of available resources in working capital in a way to attain and maintain optimal level of liquidity is mandatory, the study further set up the association of cash conversion cycle with the required minimal level of liquidity in a way that if at times cash conversion cycle increases the minimal level required for liquidity gets to upper levels; and if at times the cash conversion cycle decreases the minimal level required for liquidity moves down to lower levels. Shin \& Soenen (1998) found significant impact of efficient cash cycle conversion management on profitability and liquidity of companies

Lyroudi \& Lazaridis (2000) argues that the company's profitability depends on working capital management. Lyroudi and Lazaridis (2000) provided some evidence that cash conversion cycle significantly affects the liquidity of the company. Filbeck \& Krueger (2003) investigated that there are some other factors that affect the working capital management like interest rate, if the interest rate rises it will make longer the cash cycle period. Deloof (2003) stated that for better performance the time duration for collection of receivable should be kept short. Nobanee et al. (2004) suggested that for better performance of company inventory must be converted into cash as early as possible. Eljelly (2004) found significantly inverse association and linkage between the profitability and the liquidity represented by the cash conversion cycle.

Padachi (2006) found that if the firm is invested higher in the inventories then the optimum level will diminish and profit will go down. Teruel \& Solano (2007) explained that company's profitability would be increased by reducing days in receivables, days in inventories and length of cash cycle. Hutchison et al. (2007) observed significant association of cash conversion cycle with the return on investments of the companies. Raheman \& Nasr (2007) reported significant and negative association of components of liquidity with profitability. Hutchison et al. (2007) suggested an inverse relationship between profitability and cash conversion cycle. Teruel \& Solano (2007) suggested that firm should delay in making the payments for efficient performance. Raheman \& Nasr (2007) stated that for better performance the time duration for collection of receivable should be kept short. Appuhami (2008) investigated that operating cash flows have significant impact of firm working capital management. Koumanakos (2008) stated that the higher the average inventories are conserved the lower the rate of return. 
Afza \& Nazir (2009) found a significantly positive relationship of woeking capital management and profitability. Uyar (2009) also found significant association and linkage of working capital management with liquidity and profitability and concluded that the firm size is negatively linked and related to cash conversion cycle and a negative and oppositely moving linkage of cash conversion cycle with profitability was observed. Luo et al. (2009) stated that if the value of the firm enhances the cash cycle will decrease. Gill et al. (2010) found that if the firm is maintaining it accounts receivable, accounts payable and inventories at optimum level the firm will generate maximum profit. Dong \& Su (2010) observed significant association of cash conversion cycle with the return on investments of the companies. Sharma \& Kumar (2010) found that in Indian firm length of cash cycle and profitability have positive relationship between them. Randall \& Farris (2010) argued that by implementing a collaborative cash to cash management cycle by adopting weighted average cost of capital will increase the profitability. Johnson \& Templar (2011) stated that return on capital employed and length of cash cycle would be enhanced by change of proxy. Ebaid (2011) examined that the current cash flows have significant impact to enhance the profitability of the firm.

\section{Rationale of Study}

\section{Methodology}

The rationale of the research is to examine the impact of length of cash cycle management on profitability. Earlier literature depicts mixed results, hence it may be concluded that the relationship must be investigated further under different settings to better generalize the results for future propositions in this regard. So in this research return on equity and return on assets are taken as proxies of profitability to identify and measure the association and relationship between length of cash conversion cycle and profitability as measured by return on assets and return on equity, while taking size of firm and debt ratio as control variables.

\section{Measurement of Dependent, Independent \& Control Variables}

The study takes return on equity and return on assets as measures of profitability to represent dependent variables. It explains how firm and organizations can increase their revenue and generate sales by utilizing the available resources optimally. Firm size and debt ratio are taken as control variables whereas cash conversion cycle is considered as independent variable. The studied variables are calculated as follows:

Inventory Holding Period = (Average Inventories/Cost of Goods Sold $) \times 365$

Receivables Collection Period $=($ Average Accounts Receivables/Sales $)$ x 365

Payables Payment Period $=($ Average Accounts Payables/Cost of Purchases $) \times 365$

Cash Conversion Cycle $=$ Inventory Holding Period + Receivables Collection Period - Payables Payment Period Return on Assets $=$ Net Profit/Average Total Assets

Return on Equity $=$ Net Profit/Average Total Shareholders' Equity

Size of Firm $=$ Natural Log of Sales

Debt $=$ Average Total Debt $/$ Average Total Assets

\section{Research Model}

On the basis of review of the literature; following relationships have been predicted to be further tested statistically to conclude the results of the study.

$\mathrm{ROA}_{\mathrm{it}}=\alpha+\beta_{1}$ Size $_{\mathrm{it}}+\beta_{2}$ Debt $_{\mathrm{it}}+\beta_{3} \mathrm{CCC}_{\mathrm{it}}+\mathrm{e}_{\mathrm{it}}$

$\mathrm{ROE}_{\mathrm{it}}=\alpha+\beta_{1}$ Size $_{\mathrm{it}}+\beta_{2}$ Debt $_{\mathrm{it}}+\beta_{3} \mathrm{CCC}_{\mathrm{it}}+\mathrm{e}_{\mathrm{it}}$

Where;

ROE $=$ Return on Equity

$\mathrm{ROA}=$ Return on Assets

$\mathrm{CCC}=$ Cash Conversion Cycle

Size $=$ Natural Log of Sales

Debt $=$ Financial Debt Level

$\alpha=$ Constant Term

$\beta=$ Coefficient Term

$\mathrm{i}=$ No of firms ranging from 1- 75

$\mathrm{t}=$ Time Period ranging from $2007-2011$

$\mathrm{e}=$ Error term

\section{Population \& Sampling}

For the purpose of the study the manufacturing companies of Pakistan listed at Karachi Stock Exchange are taken to measure the impact of cash conversion cycle on profitability of the studied sector. 155 manufacturing companies are selected on the basis of availability of information for the period of study under review. 
Period of Study

Study takes into consideration 5 years financial statements data starting from 2007 to 2011

\section{Data Collection}

Secondary data is collected through five years financial statements data published by State Bank of Pakistan in form of Balance Sheet Analysis.

\section{Hypotheses}

H1: $\quad$ Cash conversion cycle has a significant inverse association with return on assets

H2: Cash conversion cycle has a significant inverse association with return on equity

\section{Data Analysis}

The descriptive analysis shown in table 1 below depicts that the mean value of the variable return on asset is around 8 percent and return on equity is around 38 percent with standard deviation of 0.08 and 1.15 respectively; the mean value for cash conversion cycle of all the companies together is around 21 days with high standard deviation. Hence it may be concluded that the on an average, manufacturing companies are facing low profitability as represented by return on assets and high profitability as represented by return on equity. Average firms are having good cash conversion cycle, but the high standard deviation tells that the firms are dispersed widely on it.

\section{Table 1}

Descriptive Statistics

\begin{tabular}{|l|l|l|l|l|l|}
\hline \multicolumn{1}{|c|}{ Variables } & \multicolumn{1}{c|}{ Obs } & \multicolumn{1}{c|}{ Mean } & \multicolumn{1}{|c|}{ Std. Dev. } & \multicolumn{1}{c|}{ Min } & \multicolumn{1}{c|}{ Max } \\
\hline ROA & 775 & 0.083 & 0.0884 & 0.0002 & 0.534 \\
\hline ROE & 775 & 0.375 & 1.1584 & 0.0005 & 20.190 \\
\hline CCC & 775 & 20.615 & 119.397 & -385.728 & 1072.255 \\
\hline SIZE & 775 & 14.207 & 1.154 & 10.793 & 17.648 \\
\hline DEBT & 775 & 0.470 & $0 . .266$ & 0.0003 & 2.599 \\
\hline
\end{tabular}

Correlation Matrix is used to find the relationship between different variables. The correlation matrix table below discloses that there is positive and moderate correlation between cash conversion cycle and size. Similarly negative and weak correlation of cash conversion cycle was observed with debt level, return on assets and return on equity.

Table 2

Correlation Matrix

\begin{tabular}{|l|l|l|l|l|l|}
\hline & CCC & SIZE & DEBT & ROA & ROE \\
\hline CCC & 1 & 0.4116 & -0.0502 & -0.1074 & -0.1126 \\
\hline SIZE & 0.4116 & 1 & -0.0413 & -0.0760 & -0.0623 \\
\hline DEBT & -0.0502 & -0.0413 & 1 & -0.0092 & 0.0927 \\
\hline ROA & -0.1074 & -0.0760 & -0.0092 & 1 & \\
\hline ROE & -0.1126 & -0.0623 & 0.0927 & & 1 \\
\hline
\end{tabular}

In order to check relationship between the studied variables, regression analysis is used after adjusting for heteroskedasticity of data to minimize the effects of outliers. Such a robust regression analysis finds out the effect and relationship of certain variable with other variables. Return on assets and return on equity are separately regressed with independent and control variables to get the outcomes of the predicted relationships.

Results of regression analysis with return on assets are shown in table 3 below. The results show that the cash conversion cycle is significantly and inversely related to return on assets indicating that lesser the cash conversion cycle greater would be the profitability as measured by return on assets. Hence the receivable collection period and inventory selling period must be reduced and payment period must be delayed to increase the profitability of manufacturing sector organizations. In other words an increase in receivable collection period and inventory selling period and decrease in payment period will adversely affect the profitability. The results supported the acceptance of H1. Size and debt as control variables are insignificant. 
Table 3

Regression Results - Return on Assets

\begin{tabular}{|l|l|l|l|l|}
\hline & Coefficient & $\begin{array}{l}\text { Standard } \\
\text { Error }\end{array}$ & $\mathrm{t}$ & Prob \\
\hline CCC & -.0000677 & .0000266 & -2.54 & 0.011 \\
\hline SIZE & -.002951 & .0028246 & -1.04 & 0.296 \\
\hline DEBT & -.0047423 & .0232858 & -0.20 & 0.839 \\
\hline Constant & .1282545 & .0404527 & 3.17 & 0.002 \\
\hline
\end{tabular}

The above results can be expressed as follows:

$\mathrm{ROA}_{\mathrm{it}}=0.1282545-0.002951 \mathrm{Size}_{\mathrm{it}}-0.0047423 \mathrm{Debt}_{\mathrm{it}}-0.0000677 \mathrm{CCC}_{\mathrm{it}}+\mathrm{e}_{\mathrm{it}}$

Results of regression analysis with return on equity are shown in table 4 below. The results show that the cash conversion cycle is significantly and inversely related to return on equity indicating that lesser the cash conversion cycle greater would be the profitability as measured by return on equity. Hence the receivable collection period and inventory selling period must be reduced and payment period must be delayed to increase the profitability of manufacturing sector organizations. In other words an increase in receivable collection period and inventory selling period and decrease in payment period will adversely affect the profitability. The results supported the acceptance of $\mathrm{H} 2$. Size and debt as control variables are insignificant.

Table 4

Regression Results - Return on Equity

\begin{tabular}{|l|l|l|l|l|}
\hline & Coefficient & $\begin{array}{l}\text { Standard } \\
\text { Error }\end{array}$ & $\mathrm{t}$ & Prob \\
\hline CCC & -.0009802 & .000377 & -2.60 & 0.009 \\
\hline SIZE & -.0167716 & .0222365 & -0.75 & 0.451 \\
\hline DEBT & .3791425 & .1916374 & 1.98 & 0.048 \\
\hline Constant & .4560128 & .2944844 & 1.55 & 0.122 \\
\hline
\end{tabular}

The above results can be expressed as follows:

$\mathrm{ROE}_{\mathrm{it}}=0.4560128-0.0167716 \mathrm{Size}_{\mathrm{it}}+0.3791425 \mathrm{Debt}_{\mathrm{it}}-0.0009802 \mathrm{CCC}_{\mathrm{it}}+\mathrm{e}_{\mathrm{it}}$

\section{Conclusion}

Cash conversion cycle is significant for every manufacturing company since it helps the financial managers to figure out the inventory holding period as reflected by the total number of days the cash of a company remains blocked in to the business operations cycle starting from the manufacturing of inventory till selling of that inventory. Cash cycle is very powerful tool for examining how well a manufacturing company's working capital is being managed. Financial managers have to run the manufacturing companies for longer period and for that they make decisions to manage working capital by creating a balance between the available current assets and current liabilities. Moreover the financial managers can reduce the risk of future shortfall of cash and bankruptcy by managing cash conversion cycle well. In the present study, cash conversion cycle of individual manufacturing firms and the overall cash conversion cycle of the manufacturing industry highlighted the performance of these firms and industry in perspective of liquidity management and its impact on profitability. It also pointed out the areas where further improvement is required regarding optimizing the cash conversion cycle. The study found an inverse and significant association and linkage of cash conversion cycle with profitability of manufacturing companies and concluded that cash conversion cycle has an opposite effect on return on assets and return on equity; hence cash conversion cycle of manufacturing firms is negatively related to the profitability of the firms. This depicts that shorter cash conversion cycle, inventory conversion period and receivables period of the firms will lead towards increased profitability of the manufacturing firms whereas longer cash conversion cycle, inventory conversion period and receivables period of the firms will lead towards decreased profitability of the manufacturing firms. Moreover earlier payments to creditors will lead towards decreased profitability of the manufacturing firms whereas extended payment periods to creditors of the firms will lead towards increased profitability of the manufacturing firms. The manufacturing companies are required to well estimate and evaluate the cash flows of the business, to well identify the long run and short run cash inflows and outflows to timely sort out the cash shortages and excess to formulate financing and investing strategies respectively. Moreover due to changing world economy, advancement of technology and increased global competition among the manufacturing companies, these companies must strive to enhance their profits by putting every effort to bring their cash conversion cycle at optimum level to increase profitability. 


\section{References}

[1] Afza, T., \& Nazir, M. (2009). Impact of aggressive working capital management policy on firms' profitability. The IUP Journal of Applied Finance, 15(8), 20-30.

[2] Alipour, M. (2011). Working capital management and corporate profitability: Evidance from Iran. World applied sciences journal,12(7),1093-1099.

[3] Appuhami, B.A Ranjith (2008). The Impact of Firms' Capital Expenditure on Working Capital Management: An Empirical Study across Industries in Thailand. International Management Review Vol. 4 No. 1

[4] Danuletiu, A.E. (2010). Working capital management and profitability: A case of ALBA country companies. Annales Universitatis Apulensis Series Oeconomica, 12(1).

[5] Deloof, M., (2003). Does working capital management affect profitability of Belgian firms. Journal of Business and Finance Accounting., 30: 573-587.

[6] Demirgunes, K. and Samiloglu, F. (2008). The effect of working capital management on firm profitability: Evidence from Turkey. International Journal of applied economics and finance, 2(1), 44-50.

[7] Dong, H.P., Su, J., (2010). The Relationship between Working Capital Management and Profitability: A Vietnam Case. International Research Journal of Finance and Economics ISSN 1450-2887.

[8] Ebaid, I. E. (2011). Accruals and the prediction of future cash flows Empirical evidence from an emerging market, Management Research Review, 34(7), 838-853.

[9] Eljelly, A. (2004). Liquidity-Profitability Tradeoff: An empirical Investigation in an Emerging Market. International Journal of Commerce \& Management, Vol 14 No 2 pp. $48-61$

[10] Enqvist, J., Graham, M. \& Nikkinen, J. (2008). The impact of working capital management on firms frofitability in different business cycles: Evidence from Finland. Retrieved from http://ssrn.com/abstract=1794802.

[11] Farris II, M. T. and Hutchison, P. D., (2002). Cash-to-cash: the new supply chain management metric. International Journal of Physical Distribution \& Logistics Management, Vol. 32 No. 4, pp. 288-298

[12] Filbeck, G. and Krueger, T.M. (2003). An Analysis of Working Capital Management Results across Industries, Mid American Journal of business, 20(2).

[13] Gentry, J.A., Vaidyanathan, Lee, R., and Wai, H., (1990), A Weighted Cash Conversion Cycle, Financial Management, Vol. 19 (No. 1, Spring),, pp. 90-99.

[14] Gill, A., Biger, N. and Mathur, N. (2010). The Relationship Between Working Capital Management And Profitability: Evidence From The United States, Business and Economics Journal.

[15] Johnson, M. and Templar, S. (2011). The relationships between supply chain and firm performance the development and testing of a unified proxy, International Journal of Physical Distribution \& Logistics Management, 41(2), 88-103.

[16] Koumanakos, D.P. (2008). The effect of inventory management on firm performance, International Journal of productivity and performance management, 57(5), 335-369.

[17] Kumar, S. and Sharma, A.K. (2011). Effect of working capital management on firm profitability: Empirical evidence from India. Global Business Review,12(1), 159-173.

[18] Lamberson, M. (1991). Changes in Working Capital of small Firms in relation to changes in Economic Activity, Mid American Journal of business, 10(2).

[19] Lazaridis, D.I. and Tryfonidis, D. (2006).The relationship between working capital management and profitability of listed companies in the Athens Stock Exchange, Retrieved from http://ssrn.com/abstract=931591.

[20] Luo, M.M., Yee Lee, J.J. and Hwang, Y. (2009). Cash Conversion Cycle, Firm Performance and Stock Value, Retrieved from http://www90.homepage.villanova.edu/michael.pagano/ML_CCC_20090420.pdf.

[21] Lyroudi, K. and Lazaridis, J. (2000). The cash conversion cycle and liquidity analysis of the food industry in Greece, Retrie ved from http://papers.ssrn.com/paper.taf?abstract_id=236175.

[22] Mathuva, D.M. (2010). The influence of working capital management components on corporate profitability: A survey on Kenyan Listed firms. Research Journal of Business Management, 4(1), 1-11.

[23] Nobanee, H. (2005). Working Capital Management and Firm's Profitability: An Optimal Cash Conversion Cycle, Retrieved from http://ssrn.com/abstract=1471230.

[24] Nobanee, H., Abdullatif, M. and AlHajjar, M. (2004). Cash Conversion Cycle and Firm's Performance of Japanese Firms, Emerald group of publishing limited.

[25] Nobanee, Haitham \& Al Hajjar, Maryam, Working Capital Management and Firm's Profitability: An Optimal Cash Conversion Cycle, August 13, 2012, Available at SSRN: http://ssrn.com/abstract=2128662

[26] Padachi, K. (2006). Trends in Working Capital Management and its Impact on Firms' Performance: An Analysis of Mauritian Small Manufacturing Firms, International Review of Business Research Papers, 2(2), 45-58.

[27] Petersen, M.A. and Rajan, R.G. (1997). Trade credit: Theories and Evidence. Oxford Journals of Economics and Social Sciences Review of Financial Studies, 10(3), 661-691.

[28] Raheman A., Afza, T., Qayyum, A. and Bodla, M.A. (2010). Working Capital Management and Corporate Performance of Manufacturing Sector in Pakistan. International Research Journal of Finance and Economics.

[29] Raheman, A. and Nasr, M. (2007). Working Capital Management and Profitability - Case Of Pakistani Firms, International Review of Business Research Papers, 3(1), 279-300.

[30] Randall, W.S. and Farris,M.T. (2010). Supply chain financing: using cash to cash variables to strengthen the supply chain, International journal of Physical Distribution and logistics management, 39(8), 669-689.

[31] Richards, V.D., and Laughlin, E.J., (1980), A Cash Conversion Cycle Approach to Liquidity Analysis, Financial Management, Vol. 9 (1), pp. 32-38.

[32] Schilling, G., 1996. "Working capital's role in maintaining corporate liquidity”, TMA Journal,

[33] Shin, H., and L. Soenen, (1998), "Efficiency of Working Capital and Corporate Profitability", Financial Practice and Education, Vol. 8, pp. 37-45.

[34] Stephanou, M., Elfani, M. and Lois, P. (2010). The effect if working capital; management on firm's profitability: Empirical evidence from an emerging market. Journal of Business \& Economics Research, 8(12).

[35] Teruel, P.J.G. and Solano,P.M. (2007). Effects of working capital management on SME profitability. International journal of Managerial Finance, 3(2), 164-177.

[36] Uyar, A. (2009). The Relationship of Cash Conversion Cycle with Firm Size and Profitability: An Empirical Investigation in Turkey. International Research Journal of Finance and Economics, Issue 24

[37] Vaidya, R..R. (2011). The determinants of trade credit: Evidence from Indian Manufacturing Firms. Modern Economy, 2, 707-716, Vol. 16 No. 5, pp. 4-7. 